\title{
Elevated levels of miR-181c and miR-633 in the CSF of patients with MS
}

\section{A validation study}

Svenja Kramer, * Arash Haghikia, MD, Claudia Bang, PhD, Kristian Scherf, Angelika Pfanne, Alexander Duscha, MSc, Johannes Kaisler, MSc, Barbara Gisevius, MSc, Ralf Gold, MD, Thomas Thum, MD, PhD, $†$ and Aiden Haghikia, MD*†

Neurol Neuroimmunol Neuroinflamm 2019;6:e623. doi:10.1212/NXI.0000000000000623

\section{Abstract}

\section{Objective}

To validate a previously discovered microRNA (miRNA) panel in the CSF of patients with MS, we now tested the diagnostic value of CSF-derived candidate miRNAs in a case-control study in a larger MS cohort.

\section{Methods}

The levels of miR-181c, miR-633, and miR-922 were analyzed in the CSF of 218 patients with MS and 211 patients with other neurologic diseases (OND) by real-time quantitative reverse transcriptase PCR.

\section{Results}

CSF levels of both miR-181c ( $p<0.001$ and miR-633 $p<0.001)$ were higher in patients with MS patients compared with patients with OND. Both miR-181c (area under the curve [AUC] 0.75, 95\% CI 0.70-0.80, $p<0.001$ ) and miR-633 (AUC 0.75, 95\% CI 0.68-0.83, $p<0.001$ ) differentiated MS from OND. Combining both miRNAs yielded a sensitivity of $62 \%$ and specificity of $89 \%$ to differentiate MS from OND. miR-922 was not confirmed to be differentially expressed in this validation cohort.

\section{Conclusions}

The results of this so far largest study on CSF-based miRNAs confirm the diagnostic value of miR-181c and miR-633 for MS. The present study may help to extend the diagnostic tools for patients with suspected MS and may add further knowledge to the pathology of the disease.

\section{Classification of Evidence}

This study provides Class III evidence that CSF-derived miR-181c and miR-633 distinguish patients with MS from patients with OND.

\author{
Correspondence \\ Dr. Haghikia \\ aiden.haghikia@rub.de
}

\section{MORE ONLINE \\ $\rightarrow$ Class of Evidence \\ Criteria for rating therapeutic and diagnostic studies \\ NPub.org/coe}

\footnotetext{
*These authors contributed equally as first authors.

tThese authors contributed equally as senior authors.

From the Department of Neurology (S.K., A.D., J.K., B.G., R.G., Aiden Haghikia), St. Josef-Hospital, Ruhr-University Bochum; Department of Cardiology (Arash Haghikia), Campus Benjamin Franklin, Charité Universitätsmedizin-Berlin; Institute of Molecular and Translational Therapeutic Strategies (IMTTS) (C.B., K.S., A.P., T.T.), Hannover Medical School; and REBIRTH Excellence Cluster (T.T.), Hannover Medical School, Germany.

Go to Neurology.org/NN for full disclosures. Funding information is provided at the end of the article.

The Article Processing Charge was funded by the authors.

This is an open access article distributed under the terms of the Creative Commons Attribution-NonCommercial-NoDerivatives License 4.0 (CC BY-NC-ND), which permits downloading and sharing the work provided it is properly cited. The work cannot be changed in any way or used commercially without permission from the journal.
} 


\section{Glossary}

AUC $=$ area under the curve; miRNA = microRNA; MSR 1 = macrophage scavenger receptor 1 ; NMO = neuromyelitis optica; $\mathbf{O C B}=$ oligoclonal band; $\mathbf{O N D}=$ other neurologic diseases; PPMS = primary progressive MS; RR = relative risk; RRMS = relapsing-remitting MS; SPMS = secondary progressive MS.

MS is the most common nontraumatic neurologic disease in young adults in Western countries. ${ }^{1,2}$ The disease is characterized by a chronic inflammatory process causing a demyelination in the CNS leading to diverse clinical manifestations. ${ }^{1}$ Despite significant improvement in rapid diagnostics by MRI, in some cases, early diagnosis is challenged by unspecific symptoms and missing clear-cut test results. Early diagnosis of disease and early treatment, however, determines the patients' prognosis by reducing the risk of disease progression and delaying disability. ${ }^{3}$ In addition, to date, there are no reliable markers to distinguish between the different courses of disease, i.e., the relapsingremitting vs progressive forms of MS. Hence, finding sensitive biomarkers that help to facilitate the diagnostic process more reliably may improve the patients' clinical outcome.

Recent identification of disease-specific markers, such as causal antibodies in aquaporin4-ab-positive neuromyelitis optica (NMO) helps to differentiate autoimmune inflammatory CNS disorders from MS.

In the past decade, numerous studies in the field of RNA research have shown microRNAs (miRNAs) to be present in different biofluids, such as serum and urine, and to serve as potential biomarkers of various diseases. 4

MiRNAs are a class of small noncoding RNAs that regulate gene expression on the posttranscriptional level and play an instrumental role in almost every biological process. ${ }^{6}$ In the neuroscientific field, these regulatory RNAs are known to play a substantial role in neuronal development and, if deregulated, directly contribute to neurologic diseases, such as neurodegenerative and neuroinflammatory diseases. ${ }^{7}$

We previously identified in a case-control profiling study 3 miRNAs that were differentially expressed in the CSF of patients with MS, miR-181c, miR-633, and miR-922. ${ }^{8}$

However, given the small cohort size of the initial study, the findings were interpreted with caution requiring further validation in larger cohorts. Here, we evaluated the diagnostic implication of these miRNAs in this so far largest study on CSF-based miRNAs.

\section{Methods}

\section{Study population and design}

The primary research question was whether one can distinguish patients with MS from patients with other neurologic diseases (OND) by the help of the CSF-derived miR-181c and miR-633
(Class III level of evidence). Since February 2009, the remaining CSF of samples obtained from patients with MS and OND for routine diagnostic and therapeutic purposes was collected and stored at $-80^{\circ} \mathrm{C}$ after written informed consent in accordance with the Ruhr-University Bochum ethics committee standard on CSF sample collection (No. 4493-12). For this study, we analyzed the CSF of 218 patients having MS with clinically well-defined disease courses and 211 patients with OND. Details of the study population are summarized in the table. The chosen individuals are a mixed cohort comprising both untreated patients and patients who underwent different forms of therapy, such as azathioprine, interferons, glatiramer acetate, mitoxantrone, natalizumab, fingolimod, or fumaric acid.

\section{Standard protocol approvals, registrations, and patient consents}

This study was approved by Ruhr-University of Bochum and Hannover Medical School and followed the tenets of the Declaration of Helsinki. Written informed consent was obtained from all participants.

\section{Quantification of miRNAs}

\section{RNA isolation}

Before freezing, cell numbers were recorded for diagnostic purposes, and hemorrhagic samples were excluded. All cells and debris in CSF samples were removed by centrifugation. After adding spiked-in control Caenorhabditis elegans miR39 as an internal control, total RNA was isolated from 200 microliter CSF using the miRNeasy Mini Kit (Qiagen, Hilden, Germany), according to the manufacturer's instructions.

\section{Quantitative reverse transcriptase PCR}

MiR-181c, miR-633, and miR-922 were validated by quantitative stem loop miRNA reverse transcriptase PCR technology (TaqMan MicroRNA Assays; Applied Biosystems, Foster City, CA) in $n=218$ patients with MS and $n=211$ patients with OND. The stem loop structure and reverse transcription primer, and after reverse transcription, the TaqMan hybridization probes for miRNA amplification provide high specificity for the quantification of only mature miRNAs. Values were normalized to spiked-in cel-miR-39 by the $\Delta \mathrm{Ct}$ method and are expressed as Starting Quantity (microRNA)/Starting Quantity (cel-miR-39). All samples were measured in duplicates, and mean values are given.

\section{Statistical analysis}

Values are given as mean $\pm S D$ or range. Comparison of mean values was performed by 2 -sided nonparametric $t$ test (MannWhitney test). One-way analysis of variance (ANOVA), 
Table Patients' characteristics

\begin{tabular}{|c|c|c|c|}
\hline & Age, y, mean (range) & Sex, F:M & Disease duration, $y$, mean, range \\
\hline \multicolumn{4}{|l|}{ Patients with MS } \\
\hline RRMS ( $n=81)$ & $53.4(19-74)$ & $1.86: 1$ & $10(2-29)$ \\
\hline SPMS $(n=106)$ & $56.0(32-77)$ & $1.65: 1$ & $19(2-45)$ \\
\hline PPMS $(n=12)$ & $62.3(40-78)$ & $2: 1$ & $14(4-26)$ \\
\hline \multicolumn{4}{|l|}{ Patients with OND } \\
\hline Vascular $(n=43)$ & $64.1(31-94)$ & $1.75: 1$ & \\
\hline Degenerative $(n=53)$ & $62.5(17-88)$ & $1.12: 1$ & \\
\hline Inflammatory $(n=58)$ & $53.7(23-86)$ & $1.32: 1$ & \\
\hline None $(n=57)$ & $48.7(11-85)$ & $1.15: 1$ & \\
\hline NMO $(n=4)$ & $41.3(27-52)$ & $2: 1$ & \\
\hline $\operatorname{CIS}(n=3)$ & $33.0(28-38)$ & $0: 2$ & \\
\hline
\end{tabular}

Abbreviations: $\mathrm{CIS}=$ clinically isolated syndrome; NMO = neuromyelitis optica; OND = other neurologic diseases; PPMS = primary progressive MS; RRMS = relapsing-remitting MS; SPMS = secondary progressive MS.

The subgroup of individuals having other inflammatory neurologic diseases includes encephalitis $(n=5)$, optic neuritis $(n=2)$, sarcoidosis $(n=3)$, lupus erythematodes $(n=2)$, myelitis $(n=2)$, chronic inflammatory demyelinating polyneuropathy $(n=6)$, granulomatosis with polyangiitis $(n=1)$, myasthenia $(n=2)$, peripheral nerve lesion $(n=1)$, Guillain-Barre syndrome $(n=1)$, lymphoma $(n=2)$, psoriasis $(n=1)$, meningitis $(n=2)$, vaccination reaction $(n=1)$ monoclonal gammopathy of undetermined significance (MGUS) $(n=1)$, neuroborreliosis $(n=3)$, overlap syndrome $(n=1)$, progressive multifocal leukoencephalopathy (PML) $(n=2)$, herpes infection $(n=2)$, sepsis $(n=1)$, and unknown $(n=17)$.

followed by Bonferroni multiple comparison test as a post hoc analysis was performed to compare the miRNA values between 3 or more unpaired groups (GraphPad Prism, La Jolla, $\mathrm{CA})$. Receiver operating characteristic curves were generated for specificity and sensitivity values. Logistic regression was performed for relative risks (RRs) and 95\% CIs. Spearman correlation analyses were used to evaluate the correlation between miRNA values and age, sex, and duration of disease, respectively. We also performed an ordinary 1-way ANOVA to investigate whether there is a significant correlation between the miRNA level and the medication of the analyzed patients. The following values were considered significant: ${ }^{*} p$ $<0.05,{ }^{* *} p<0.001$, and ${ }^{* * *} p<0.0001$.

\section{Data availability}

The authors confirm that the data supporting the findings of this study are available within the article and from the corresponding author upon reasonable request.

\section{Results}

miRNAs in the CSF of patients with MS and OND Quantitative miRNA reverse transcriptase PCR revealed elevated levels of miR-181c in the CSF of patients with MS compared with patients with OND (MS: $7.04 \pm 0.35, \mathrm{n}=218$ vs OND: $6.67 \pm 0.4, \mathrm{n}=211 ; p<0.001$ ) (figure $1 \mathrm{~A}$ ). Moreover, miR-181c levels differed moderately between the MS subtypes secondary progressive MS (SPMS) and relapsing remitting MS (RRMS) (SPMS: $7.08 \pm 0.36, \mathrm{n}=106 \mathrm{vs}$ RRMS: $6.97 \pm 0.32, \mathrm{n}=81 ; p=0.036)$. Comparison of miR$181 \mathrm{c}$ levels between patients with primary progressive MS
(PPMS) and patients with SPMS also revealed different values (PPMS: $6.89 \pm 0.3, \mathrm{n}=12$ vs SPMS: $7.08 \pm 0.36, \mathrm{n}=106$; $p=0.046)$. However, between patients with RRMS and PPMS, the miR-181c levels did not differ $(p=0.381)$. CSF levels of miR-181c did also not differ among patients with OND $(p=0.662)$ (figure 1A).

miR-633 was detected in the CSF of 87 patients with MS and 78 patients with OND. Analysis of CSF levels of miR-633 revealed increased levels compared with patients with OND (MS: $22.12 \pm 1.27, \mathrm{n}=87$ vs OND: $19.78 \pm 2.8, \mathrm{n}=78 ; p<$ 0.001) (figure 1B). Comparison of miR-633 levels between SPMS and PPMS showed higher levels in patients with SPMS (SPMS: $22.26 \pm 1.1, \mathrm{n}=40$ vs PPMS: $21.06 \pm 0.35, \mathrm{n}=5 ; p=$ 0.008 ) (figure 1B). miR-633 levels did not differ between RRMS and SPMS (RRMS: $22.13 \pm 1.46, \mathrm{n}=35$ vs SPMS: $22.26 \pm 1.14, \mathrm{n}=40 ; p=0.468)$ nor PPMS $(p=0.052)$, respectively (figure 1B). CSF levels of miR-633 did also not differ among patients with OND $(p=0.148)$ (figure 1B).

The CSF levels of both miRNAs in patients with NMO were within the range of patients with MS (figure 1, A and B).

Importantly, none of the miRNAs correlated with age (correlation coefficient $r=0.005$ for miR-181c; $r=0.019$ for miR-633), sex ( $r=0.001$ for miR-181c; $r<0.001$ for miR-633), or disease duration $(r<0.001$ for miR-181c; $r<$ 0.001 for miR-633). We did not detect any significant correlation between the miRNA levels and different therapies. Details of the correlation between the miR levels and treatments are shown in figure 4, A and B. In this study, we 
A
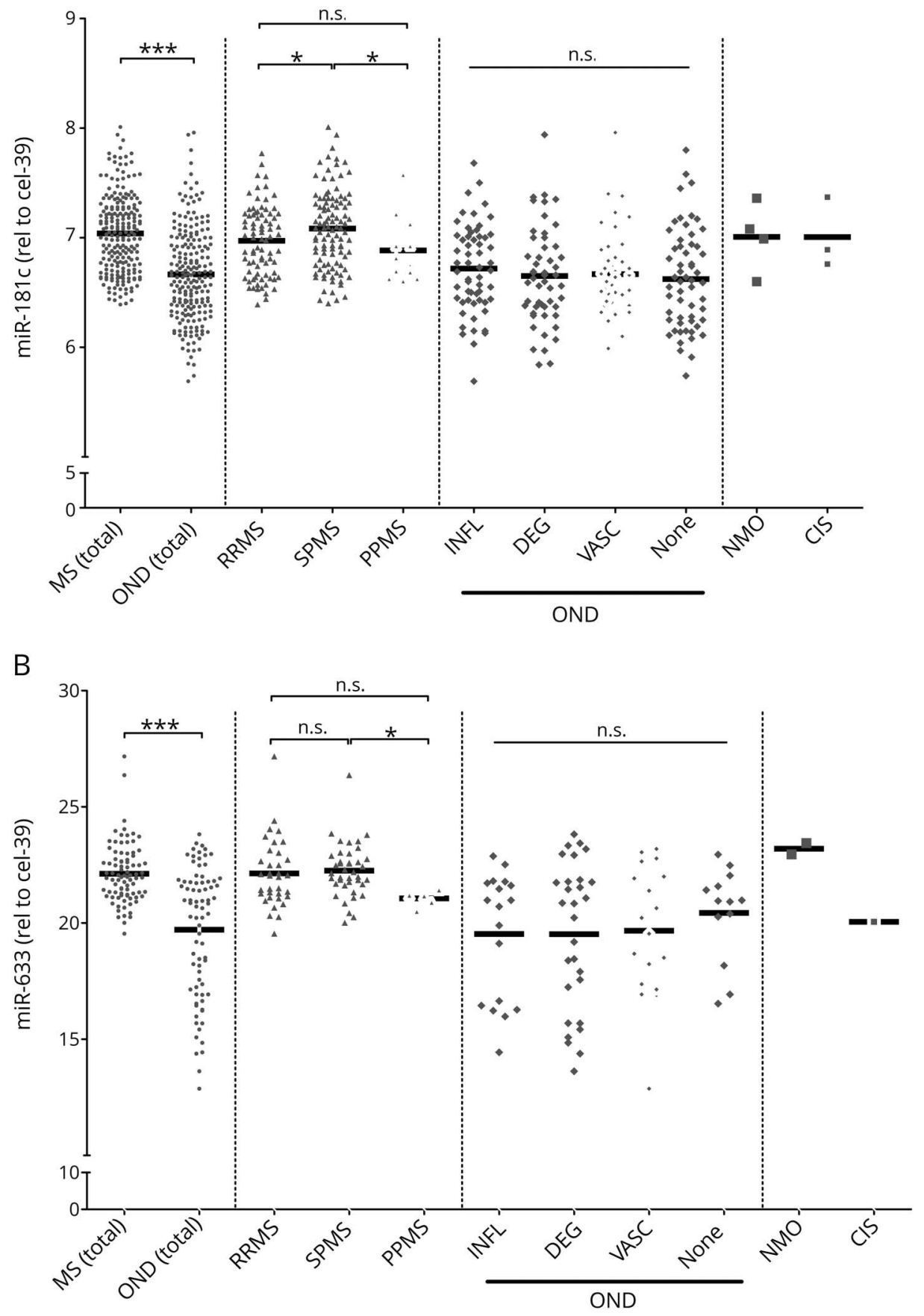
The y-axis depicts values normalized to
spiked-in cel-miR-39 and expressed as
Starting Quantity (microRNA)/Starting
Quantity (cel-miR-39) for (A) miR-181c and
(B) miR-633. The OND cohort includes
patients with inflammatory (INFL), de-
generative (DEG), vascular (VASC), and
unspecified diseases (none) of the CNS.
Black bars indicate mean values; ${ }^{*} p<0.05$,
*** $<0.001$. CIS = clinically isolated syn-
drome; NMO = neuromyelitis optica; n.S.
not significant; OND = other neurologic
diseases; PPMS = primary progressive MS;
RRMS = relapsing-remitting MS; SPMS =
secondary progressive MS.

could not validate the diagnostic value of miR-922, as its levels did not reveal any differences among the groups (data not shown).

\section{Differentiating value of candidate miRNAs}

To evaluate the predictive value of the candidate miRNAs for MS, we determined the area under the curve (AUC) of either 1 miRNA. As depicted in figure 2, the analysis revealed an AUC of 0.75 for miR-181c (95\% CI: $0.70-0.8, p<0.0001$ ) (figure 2A) and an AUC of 0.75 for miR-633 (95\% CI: 0.68-0.83, $p<$ 0.0001 ) (figure 2B). Combining both miRs in an analysis tree resulted in enhanced specificity and sensitivity values. The combination of a cutoff value $>6.79$ for miR-181c (RR 2.0; 95\% CI: $1.6-2.4$ ) and >21.53 for miR-633 (RR 1.8; 95\% CI: $1.3-2.5$ ) led to $62 \%$ sensitivity and $89 \%$ specificity for the discrimination between MS and OND (figure 3). 
A. $\operatorname{miR}-181 \mathrm{c}$

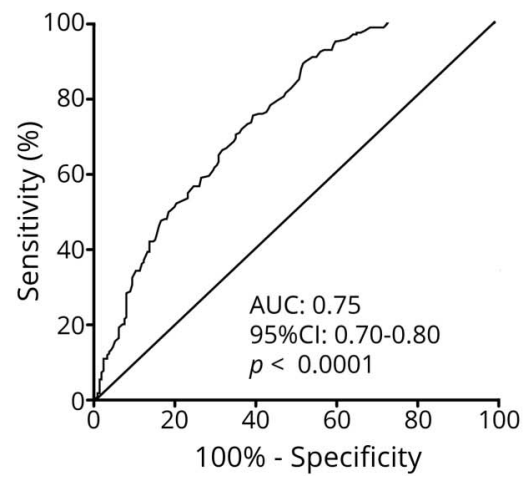

B. $\operatorname{miR}-633$

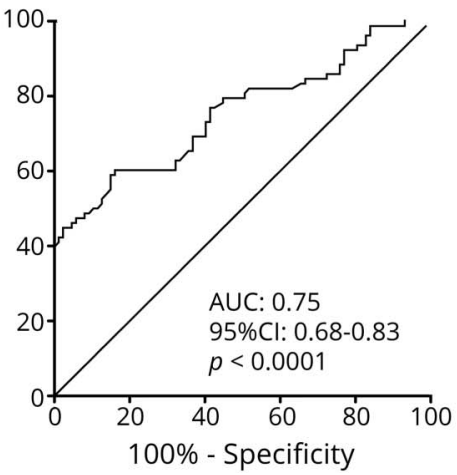

C. $\operatorname{miR}-181 c+m i R-633$

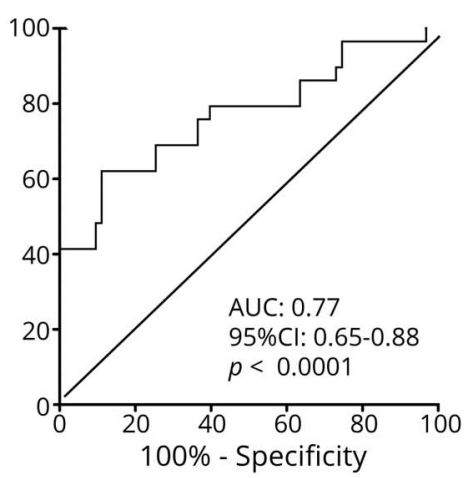

ROC curve analysis for single miRNAs (A: miR-181c; B: miR-633) to discriminate MS from OND and combinations of both miRNAs to discriminate MS from OND (C). $A \cup C=$ area under the curve; miRNA = microRNA; OND = other neurologic diseases.

\section{Discussion}

In our current large validation study, we investigated miRNAs in the CSF of patients with neurologic disorders, which we had previously identified to be altered in MS. The results of this study confirm elevated levels of 2 distinct miRNAs, miR-181c and miR-633. ${ }^{8}$ Moreover, our findings demonstrate considerable specificity and sensitivity levels of combined analysis of miR-181c and miR-633 to differentiate MS from OND including vascular, degenerative, and other inflammatory disorders of the CNS. Although we found significantly higher miR-633 levels in patients with SPMS compared with patients with PPMS, neither one of

Figure 3 Diagnostic trees of combined miRNAs

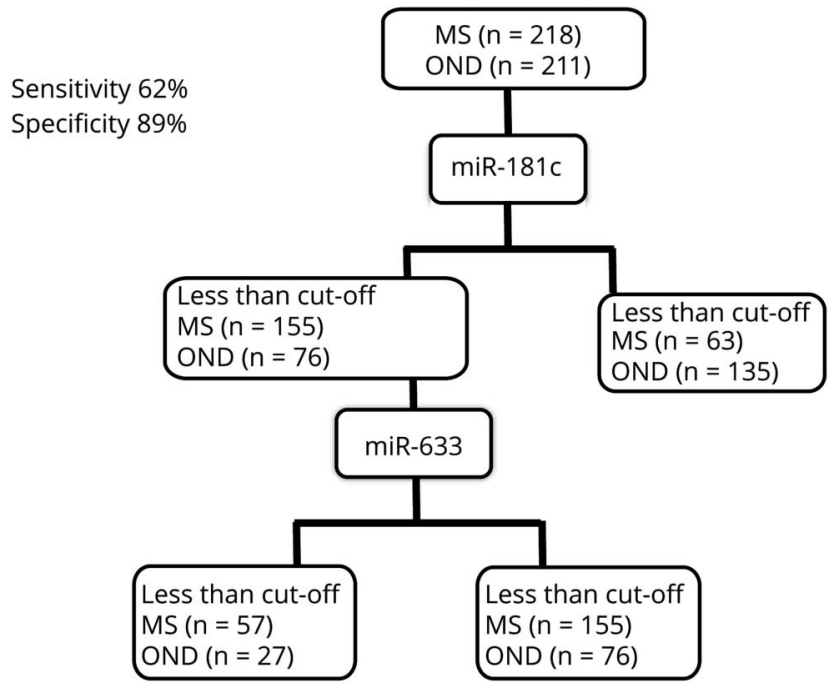

Combination of candidate microRNAs (miRNAs) in a diagnostic tree showed considerable specificity and sensitivity values to differentiate (A) MS from OND. Cutoffs used in the respective trees were $>6.79$ for miR-181c and $>21.53$ for miR-633. OND = other neurologic diseases. the miRNAs was able to discriminate between these 2 disease courses.

To date, the only reliable nonclinical measure for the diagnosis of MS is, apart from MRI lesions, the detection of oligoclonal bands (OCBs) in the CSF. ${ }^{9}$ Despite displaying a high sensitivity, OCBs have a low specificity and may be detectable in a number of inflammatory, autoimmune, or infectious disorders of the CNS. In recent years, growing evidence suggested a potential role of miRNAs as innovative markers for MS. ${ }^{7,10}$ However, most studies focused on miRNA signatures in the serum or in mononuclear cells in the peripheral blood ${ }^{9,10}$ with limited potential to assess pathologic processes of the CNS.

Analysis of deregulated miRNA patterns in the CSF more likely reflects the local milieu of the CNS under diseased conditions. In an effort to identify deregulated miRNAs in MS, we previously performed in a derivation study a miRNA transcriptome analysis including 760 miRNAs in the pooled CSF of patients with MS. ${ }^{8}$ Out of this panel, we detected 3 miRNAs, of which we confirmed mir-181c and miR-633 in the current validation study. The absolute differences between the miRNA levels of the MS cohort and the OND cohort seem small, and the clinical applicability needs to be validated. However, because of the confined compartment, i.e., CSF and the mode of action of miRNA, it remains to be seen whether absolute miRNA levels behave linearly to their biological impact. Notably, elevated CSF levels of miR-181c were recently reported to predict the conversion from a clinically isolated syndrome to $\mathrm{RRMS}^{11}$ with increased levels of miRNA-181c in the CSF in the early and highly active phase of MS. This study of an independent cohort supports the previous results on miR-181c as a marker of increased inflammatory disease activity. Furthermore, differences between the miRNA levels in serum and CSF were suggested as an indicator for 


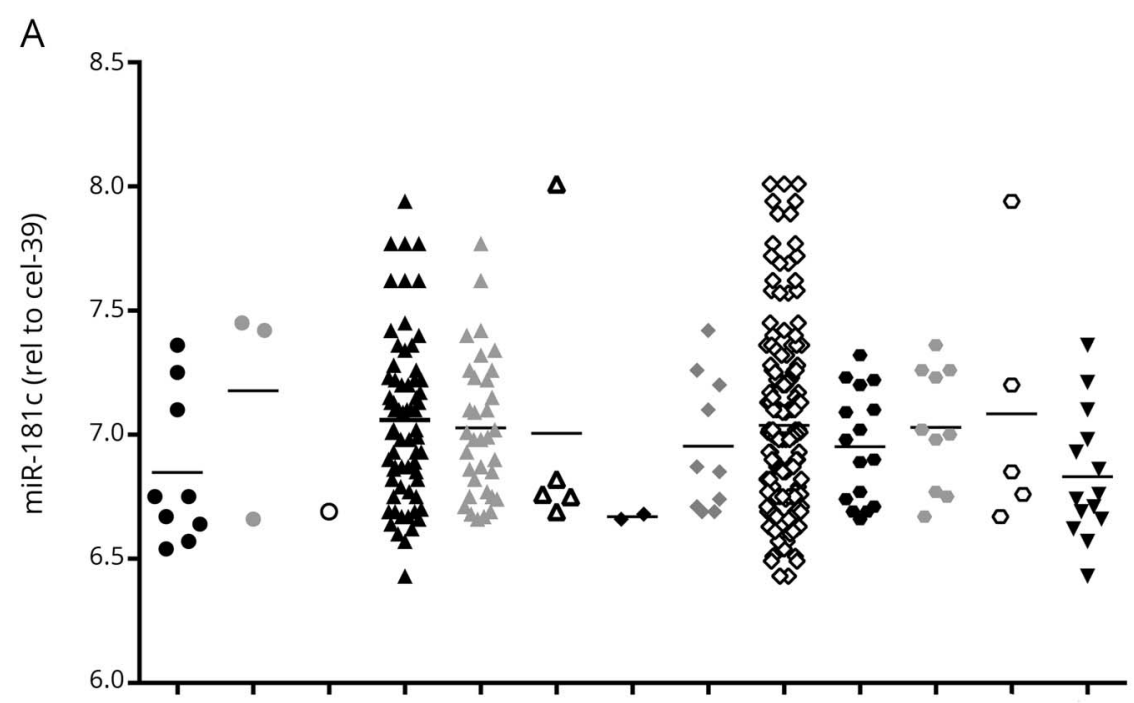

B

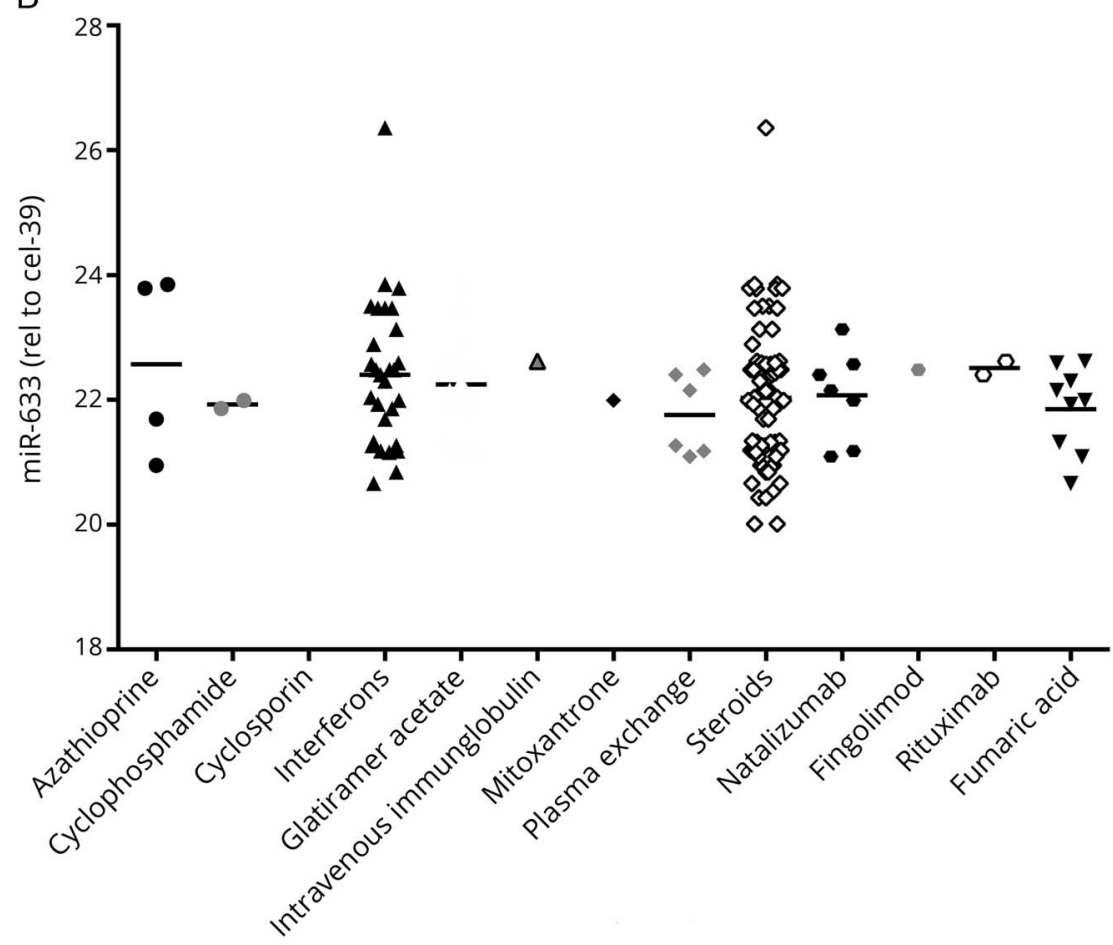

Ordinary 1-way analysis of variance reveals a potential correlation between the miR-181c and miR 633 levels on the $y$-axis and the taken medications such as azathioprine, interferons, glatiramer acetate, mitoxantrone, natalizumab, fingolimod, or fumaric acid depicted on the $x$-axis.

the blood-CSF-barrier's function further pointing to a potential value of this miR-181c for disease-monitoring purposes.

In addition to their growing clinical implication, the functional role of these miRNAs in MS-related pathophysiologic processes is now being increasingly appreciated. Experimental studies have demonstrated involvement of miR$181 \mathrm{c}$ in the regulation of neuronal maturation and synaptogenesis in the cortex ${ }^{12}$ and in the molecular responses of astrocytes under inflammatory conditions, such as exposure to lipopolysaccharide. ${ }^{13}$ Furthermore, several target genes have been identified for miR-181c including $S M A D 7$, a negative regulator of transforming growth factor beta (TGF- $\beta$ ) signaling both involved in Th17 differentiation in MS, which is a major driver of CNS autoimmunity. ${ }^{14}$ Similarly, mixed lineage leukemia-1 is a direct target for miR-181c and also involved in neuroinflammatory processes. ${ }^{15}$ Another miR-181c target, the Toll-like receptor 4, is involved in cerebral hypoxic diseases. ${ }^{16}$ In contrast, no targets for miR-633 have been validated so far. A search using the bioinformatics prediction 
tool TargetScan (Whitehead Institute for Biomedical Research, Cambridge, MA) revealed 8 potential binding sites of the macrophage scavenger receptor 1 (MSR1) for miR633. MSR1 is also discussed in the context of TGF- $\beta$ induced microglia toxicity. ${ }^{17}$ Thus, both miR-181c and miR633 (potentially) target messenger RNAs involved in neuroinflammatory pathways. This points toward a potential role of these miRs as therapeutic targets in MS.

Thus, further investigations are required to explore the potential regulatory role of these miRNAs within the pathophysiology of MS. As the distinction between the different courses of MS determines therapeutic decisions, the establishment of biomarkers allowing the discrimination between RRMS, SPMS, and PPMS is of utmost clinical importance and needs additional research.

The current study confirms our previous data on elevated CSF levels of miR-181c and miR-633 in patients with MS underscoring their diagnostic potential to differentiate MS from other diseases of the CNS. Further multicenter studies are required to validate their potential as diseases markers.

\section{Acknowledgment}

The authors thank for support by the Grant for MS Innovation (GMSI; Merck Foundation) (to A.H., R.G., and T.T.).

\section{Study funding}

This study was supported by the Grant for MS Innovation (GMSI; Merck Foundation) (to A.H., R.G., and T.T.).

\section{Disclosure}

Arash Haghikia, Aiden Haghikia, T.T., and R.G. have filed a patent for microRNA Profiling for Diagnosis of MS. Go to Neurology.org/NN for full disclosures.

\section{Publication history}

Received by Neurology: Neuroimmunology \& Neuroinflammation March 26, 2018. Accepted in final form August 20, 2019.

\section{Appendix Authors}

\begin{tabular}{llll}
\hline Name & Affiliation & Role & Contribution \\
\hline $\begin{array}{l}\text { Svenja } \\
\text { Kramer }\end{array}$ & $\begin{array}{l}\text { Department of } \\
\text { Neurology, St. Josef- } \\
\text { Hospital, Ruhr- } \\
\text { University Bochum, }\end{array}$ & $\begin{array}{l}\text { Investigator } \\
\text { and author }\end{array}$ & $\begin{array}{l}\text { Acquisition of } \\
\text { data and } \\
\text { analysis and } \\
\text { interpretation }\end{array}$ \\
& Bochum, Germany & & \\
\hline Arash & Department of & Investigator & Study concept \\
Haghikia, & Cardiology, Campus & and author & and design, \\
MD & Benjamin Franklin, & & $\begin{array}{l}\text { analysis and } \\
\text { interpretation, } \\
\text { Charité }\end{array}$ \\
& Universitätsmedizin- & & $\begin{array}{l}\text { andical } \\
\text { revision of the } \\
\text { manuscript for }\end{array}$ \\
& Berlin, Berlin, & & important \\
Germany & & $\begin{array}{l}\text { intellectual } \\
\text { content }\end{array}$ \\
& & & \\
\hline
\end{tabular}

Appendix (continued)

\begin{tabular}{|c|c|c|c|}
\hline Name & Affiliation & Role & Contribution \\
\hline $\begin{array}{l}\text { Claudia } \\
\text { Bang, PhD }\end{array}$ & $\begin{array}{l}\text { Institute of Molecular } \\
\text { and Translational } \\
\text { Therapeutic } \\
\text { Strategies (IMTTS), } \\
\text { Hannover Medical } \\
\text { School, Hannover, } \\
\text { Germany }\end{array}$ & Investigator & $\begin{array}{l}\text { Analysis and } \\
\text { interpretation }\end{array}$ \\
\hline $\begin{array}{l}\text { Kristian } \\
\text { Scherf }\end{array}$ & $\begin{array}{l}\text { Institute of } \\
\text { Molecular and } \\
\text { Translational } \\
\text { Therapeutic } \\
\text { Strategies (IMTTS), } \\
\text { Hannover Medical } \\
\text { School, Hannover, } \\
\text { Germany }\end{array}$ & Investigator & $\begin{array}{l}\text { Analysis and } \\
\text { interpretation }\end{array}$ \\
\hline $\begin{array}{l}\text { Angelika } \\
\text { Pfanne }\end{array}$ & $\begin{array}{l}\text { Institute of } \\
\text { Molecular and } \\
\text { Translational } \\
\text { Therapeutic } \\
\text { Strategies (IMTTS), } \\
\text { Hannover Medical } \\
\text { School, Hannover, } \\
\text { Germany }\end{array}$ & Investigator & $\begin{array}{l}\text { Acquisition of } \\
\text { data }\end{array}$ \\
\hline $\begin{array}{l}\text { Alexander } \\
\text { Duscha, } \\
\text { MSc }\end{array}$ & $\begin{array}{l}\text { Department of } \\
\text { Neurology, St. Josef- } \\
\text { Hospital, Ruhr- } \\
\text { University Bochum, } \\
\text { Bochum, Germany }\end{array}$ & Investigator & $\begin{array}{l}\text { Acquisition of } \\
\text { data }\end{array}$ \\
\hline $\begin{array}{l}\text { Johannes } \\
\text { Kaisler, } \\
\text { MSc }\end{array}$ & $\begin{array}{l}\text { Department of } \\
\text { Neurology, St. Josef- } \\
\text { Hospital, Ruhr- } \\
\text { University Bochum, } \\
\text { Bochum, Germany }\end{array}$ & Investigator & $\begin{array}{l}\text { Acquisition of } \\
\text { data }\end{array}$ \\
\hline $\begin{array}{l}\text { Barbara } \\
\text { Gisevius, } \\
\text { MSc }\end{array}$ & $\begin{array}{l}\text { Department of } \\
\text { Neurology, St. Josef- } \\
\text { Hospital, Ruhr- } \\
\text { University Bochum, } \\
\text { Bochum, Germany }\end{array}$ & Investigator & $\begin{array}{l}\text { Acquisition of } \\
\text { data }\end{array}$ \\
\hline $\begin{array}{l}\text { Ralf Gold, } \\
\text { MD }\end{array}$ & $\begin{array}{l}\text { Department of } \\
\text { Neurology, St. Josef- } \\
\text { Hospital, Ruhr- } \\
\text { University Bochum, } \\
\text { Bochum, Germany }\end{array}$ & Author & $\begin{array}{l}\text { Critical } \\
\text { revision of } \\
\text { the manuscript } \\
\text { for important } \\
\text { intellectual } \\
\text { content }\end{array}$ \\
\hline $\begin{array}{l}\text { Thomas } \\
\text { Thum, MD, } \\
\text { PhD }\end{array}$ & $\begin{array}{l}\text { Institute of } \\
\text { Molecular and } \\
\text { Translational } \\
\text { Therapeutic } \\
\text { Strategies (IMTTS), } \\
\text { Hannover Medical } \\
\text { School, Hannover, } \\
\text { Germany, REBIRTH } \\
\text { Excellence Cluster, } \\
\text { Hannover Medical } \\
\text { School, Hannover, } \\
\text { Germany }\end{array}$ & PI and author & $\begin{array}{l}\text { Study concept } \\
\text { and design, } \\
\text { analysis and } \\
\text { interpretation, } \\
\text { and critical } \\
\text { revision of the } \\
\text { manuscript for } \\
\text { important } \\
\text { intellectual } \\
\text { content }\end{array}$ \\
\hline $\begin{array}{l}\text { Aiden } \\
\text { Haghikia, } \\
\text { MD }\end{array}$ & $\begin{array}{l}\text { Department of } \\
\text { Neurology, St. Josef- } \\
\text { Hospital, Ruhr- } \\
\text { University Bochum, } \\
\text { Bochum, Germany }\end{array}$ & $\begin{array}{l}\text { PI and author } \\
\text { (corresponding } \\
\text { author) }\end{array}$ & $\begin{array}{l}\text { Study concept } \\
\text { and design, } \\
\text { analysis and } \\
\text { interpretation, } \\
\text { critical revision } \\
\text { of the } \\
\text { manuscript for } \\
\text { important } \\
\text { intellectual } \\
\text { content, and } \\
\text { study } \\
\text { supervision }\end{array}$ \\
\hline
\end{tabular}




\section{References}

1. Haghikia A, Hohlfeld R, Gold R, Fugger L. Therapies for multiple sclerosis: translational achievements and outstanding needs. Trends Mol Med 2013;19:309-319.

2. Maroney M, Hunter SF. Implications for multiple sclerosis in the era of the Affordable Care Act: a clinical overview. Am J Manag Care 2014;20:S220-S227.

3. Haghikia A, Gold R. Active immunotherapy may delay disability in progressive MS. J Neurol Neurosurg Psychiatry 2017;88:193.

4. Vegter EL, Schmitter D, Hagemeijer Y, et al. Use of biomarkers to establish potential role and function of circulating microRNAs in acute heart failure. Int J Cardiol 2016; 224:231-239.

5. Haj-Ahmad TA, Abdalla MA, Haj-Ahmad Y. Potential urinary miRNA biomarker candidates for the accurate detection of prostate cancer among benign prostatic hyperplasia patients. J Cancer 2014;5:182-191.

6. Bartel DP. MicroRNAs: genomics, biogenesis, mechanism, and function. Cell 2004; 116:281-297.

7. de Faria O Jr, Moore CS, Kennedy TE, Antel JP, Bar-Or A, Dhaunchak AS. MicroRNA dysregulation in multiple sclerosis. Front Genet 2012;3:311.

8. Haghikia A, Haghikia A, Hellwig K, et al. Regulated microRNAs in the CSF of patients with multiple sclerosis: a case-control study. Neurology 2012;79:2166-2170.

9. Kamm CP, Uitdehaag BM, Polman CH. Multiple sclerosis: current knowledge and future outlook. Eur Neurol 2014;72:132-141.
10. Martinelli-Boneschi F, Fenoglio C, Brambilla P, et al. MicroRNA and mRNA expression profile screening in multiple sclerosis patients to unravel novel pathogenic steps and identify potential biomarkers. Neurosci Lett 2012;508:4-8.

11. Ahlbrecht J, Martino F, Pul R, et al. Deregulation of microRNA-181c in cerebrospinal fluid of patients with clinically isolated syndrome is associated with early conversion to relapsing-remitting multiple sclerosis. Mult Scler 2016;22:1202-1214.

12. Kos A, Olde Loohuis N, Meinhardt J, et al. MicroRNA-181 promotes synaptogenesis and attenuates axonal outgrowth in cortical neurons. Cell Mol Life Sci 2016;73:3555-3567.

13. Hutchison ER, Kawamoto EM, Taub DD, et al. Evidence for miR-181 involvement in neuroinflammatory responses of astrocytes. Glia 2013;61:1018-1028.

14. Zhang Z, Xue Z, Liu Y, et al. MicroRNA-181c promotes Th17 cell differentiation and mediates experimental autoimmune encephalomyelitis. Brain Behav Immun 2018;70 305-314.

15. Yin $\mathrm{M}$, Chen Z, Ouyang $\mathrm{Y}$, et al. Thrombin-induced, TNFR-dependent miR-181c downregulation promotes MLL1 and NF-KB target gene expression in human microglia. J Neuroinflammation 2017;14:1-13. doi: 10.1186/s12974-017-0887-5.

16. Zhang L, Li YJ, Wu XY, Hong Z, Wei WS. MicroRNA-181c negatively regulates the inflammatory response in oxygen-glucose-deprived microglia by targeting Toll-like receptor 4. J Neurochem 2015;132:713-723. doi: 10.1111/jnc.13021.

17. von Bernhardi R, Cornejo F, Parada GE, Eugenín J. Role of TGF $\beta$ signaling in the pathogenesis of Alzheimer's disease. Front Cell Neurosci 2015;9:1-21. doi: 10.3389/ fncel.2015.00426. 


\section{Neurology ${ }^{\oplus}$ \\ Neuroimmunology \& Neuroinflammation}

Elevated levels of miR-181c and miR-633 in the CSF of patients with MS: A validation study

Svenja Kramer, Arash Haghikia, Claudia Bang, et al.

Neurol Neuroimmunol Neuroinflamm 2019;6; 623

DOI 10.1212/NXI.0000000000000623

This information is current as of October 1, 2019

Neurol Neuroimmunol Neuroinflamm is an official journal of the American Academy of Neurology.

Published since April 2014, it is an open-access, online-only, continuous publication journal. Copyright

Copyright $\odot 2019$ The Author(s). Published by Wolters Kluwer Health, Inc. on behalf of the American

Academy of Neurology.. All rights reserved. Online ISSN: 2332-7812.

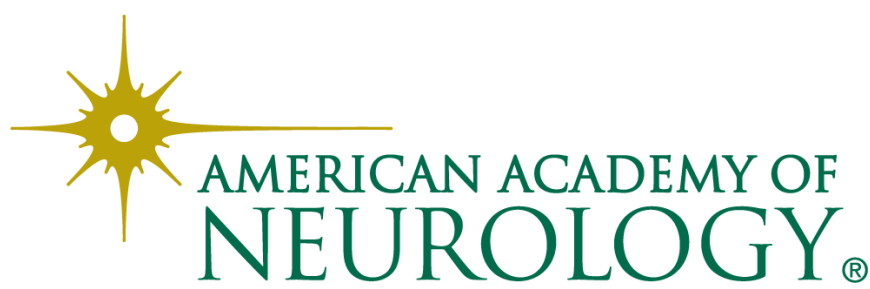




\section{Updated Information \& Services}

References

Citations

Subspecialty Collections

Permissions \& Licensing

Reprints including high resolution figures, can be found at: http://nn.neurology.org/content/6/6/e623.full.html

This article cites 17 articles, 1 of which you can access for free at: http://nn.neurology.org/content/6/6/e623.full.html\#\#ref-list-1

This article has been cited by 1 HighWire-hosted articles: http://nn.neurology.org/content/6/6/e623.full.html\#\#otherarticles

This article, along with others on similar topics, appears in the following collection(s):

Autoimmune diseases

http://nn.neurology.org//cgi/collection/autoimmune_diseases Clinical neurology examination

http://nn.neurology.org//cgi/collection/clinical_neurology_examination

\section{Multiple sclerosis}

http://nn.neurology.org//cgi/collection/multiple_sclerosis

Information about reproducing this article in parts (figures,tables) or in its entirety can be found online at:

http://nn.neurology.org/misc/about.xhtml\#permissions

Information about ordering reprints can be found online: http://nn.neurology.org/misc/addir.xhtml\#reprintsus

Neurol Neuroimmunol Neuroinflamm is an official journal of the American Academy of Neurology.

Published since April 2014, it is an open-access, online-only, continuous publication journal. Copyright

Copyright $\odot 2019$ The Author(s). Published by Wolters Kluwer Health, Inc. on behalf of the American Academy of Neurology.. All rights reserved. Online ISSN: 2332-7812.

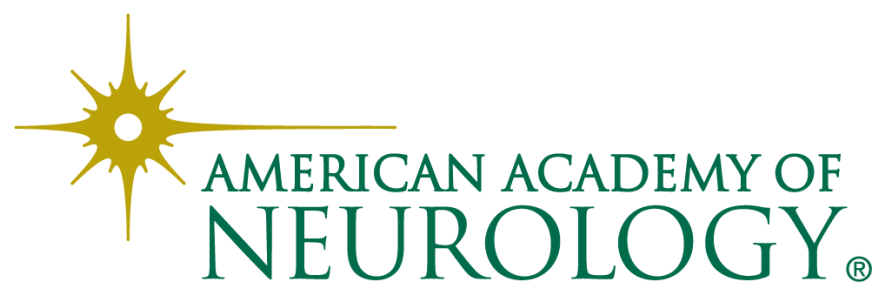

